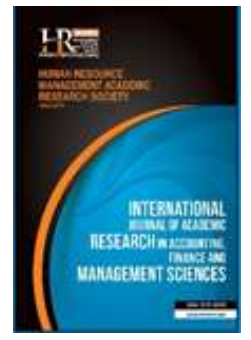

International Journal of Academic Research in Accounting, Finance and Management Sciences

Vol. 9, No.4, October 2019, pp. 84-97

E-ISSN: 2225-8329, P-ISSN: 2308-0337

(C) 2019 HRMARS

www.hrmars.com

To cite this article: Kharashgah, K. A., Amran, N. A., Binti Ishak, R. (2019). The Impact of Audit Committee

Characteristics on Real Earnings Management: Evidence from Jordan, International Journal of Academic Research

in Accounting, Finance and Management Sciences 9 (4): 84-97

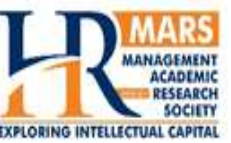

http://dx.doi.org/10.6007/IJARAFMS/v9-i4/6699 (DOI:10.6007/IJARAFMS/v9-i4/6699)

\title{
The Impact of Audit Committee Characteristics on Real Earnings Management: Evidence from Jordan
}

\author{
Khaled Ahmad Kharashgah ${ }^{1}$, Noor Afza Binti Amran ${ }^{2}$, Rokiah Binti Ishak ${ }^{3}$ \\ ${ }^{1}$ Puteri Intan Safinaz School of Accountancy (TISSA) College of Business, Universiti Utara Malaysia, Malaysia, \\ ${ }^{1}$ E-mail: Khaled.ah.oq.kh@gmail.com \\ ${ }^{2,3}$ Tunku Puteri Intan Safinaz School of Accountancy (TISSA) College of Business, Universiti Utara Malaysia, Malaysia
}

\begin{abstract}
Accounting scandals and corporate failures, like Enron, WorldCom and Toshiba, have driven the regulators to look into the importance and role of the audit committee $(A C)$ in the practicing of real earnings management (REM). This study investigates the impact of AC characteristics, i.e., size, expertise, meetings and independence, on REM using a sample of 721 firm-year observations of firms listed on the Amman Stock Exchange (ASE) for the 2011 to 2017 period. Interestingly, the results reveal that AC expertise, AC independence and $A C$ meetings have a negatively significant relationship with the level of REM; while there is no relationship between REM and AC size. The findings from the current study can help regulatory bodies and policymakers in instituting policies and strategies with regards to the credibility of financial reports in Jordan. Future studies may consider the effect of other AC characteristics, like AC quality, AC members' ownership and AC members' remuneration on REM.
\end{abstract}

Key words Audit Committee Size, Audit Committee Expertise, Audit Committee Meetings, Audit Committee Independence, Jordanian Firms, Real Earnings Management

Received: 01 Dec 2019 (C) The Authors 2019

Revised: 09 Dec 2019 Published by Human Resource Management Academic Research Society (www.hrmars.com)

Accepted: 15 Dec 2019 This article is published under the Creative Commons Attribution (CC BY 4.0) license. Anyone may reproduce, distribute, translate and create derivative works of this article (for both commercial and non-commercial purposes), subject to full attribution to the original publication and authors. The full terms of this license may be seen at: http://creativecommons.org/licences/by/4.0/legalcode

\section{Introduction}

Substantial evidences from the series of corporate events, such as bond issuance (Pae and Quinn, 2011); seasonal equity offerings (Cohen and Zarowin, 2010); Initial Public Offerings (IPOs) (Kamel, 2012); and corporate scandals, which occurred in the recent past, have signified that managers do manipulate earnings. It is also indicated that earnings reports are manipulated to increase managers' compensation if companies' performance is aligned with managers' personal benefits, job security, capital market pressure and window dressing, to influence stock valuation and for tax benefits (Healy and Wahlen, 1998). This practice is referred to as earnings management (EM).

EM can be categorized into accrual earnings management (AEM) and real earnings management (REM). AEM encompasses the activities within the constraints of the GAAPs, to cover or disguise the real accounting income of a firm (Dechow and Skinner, 2000). By contrast, REM takes place when the executives behave in a manner that strays from best practices and change reported earnings (Gunny, 2005). Compared to AEM, REM has received relatively little attention in the literature.

According to Fan (2017) and Roychowdhury (2006), REM is harmful to an organization's long-term performance, reported earnings and real economics. Cohen et al. (2008); and Roychowdhury (2006) state 
that deviation from normal operating activities are involved in alteration of true operation or activities of the firm to mislead shareholders and stakeholders regarding achievement of certain goals. Following the corporate disasters, auditors and regulatory authorities have begun to enforce more stringent conditions, whereby the managers' choice of manipulating earnings from the accrual-based technique has changed to the real action method. According to Roychowdhury (2006), REM is carried out using three important tools (overproduction, low discretionary expenses and low operating cash flows), all of which are done to maximize a firm's reported earnings. Thus, the stakeholders are attracted towards the issue of REM, including regulators, financial analysts, investors, the press and tax authorities (Xie et al., 2003).

Additionally, a study regarding REM is appropriate, as AEM has been a topic of extensive research in the field of accounting. There have been very few studies on REM explicitly in the past. Furthermore, it has also been reported that the future performance of an organization may deteriorate due to REM more than AEM (Kim and Park, 2014; Kim and Sohn, 2013; Roychowdhury, 2006). Chi et al. (2011) reported that it may be a more harmful violation of the regulations and rules. Paredes and Wheatley (2017) mentioned that for stakeholders, it is of economic importance to identify the factors that are linked to REM.

In Jordan, the issue of the practice of EM, especially REM, is both crucial and alarming compared to other countries around the world. Using a sample of 38 countries, a recent study conducted by Enomoto et al. (2015) has shown that Jordanian firms practice REM activities as high as $81 \%$ compared to other countries. Hence, the high rate of REM practiced among Jordanian firms remains a critical issue and could lead eventually to the collapse of firms and raise other economic problems, such as an increase in unemployment rate and a decrease in growth rate (European Bank, 2016).

Of late, the new regulations, as a consequence of the major corporate scandals, have ignited renewed interest in the AC (Bhasin, 2012). For the last three decades, the most popular mechanism of corporate governance seems to be the AC. Regulatory and Professional bodies in several countries have suggested a global acceptance and at the same time given support to an increased role for the $A C$ (Abdullatif, 2006; Turley and Zaman, 2004). The Basel Committee in 2001 supported the establishment of the $A C$ in firms to address the problems that might come up for the board, or if a suitable system of controls is not in place.

Many researchers have suggested that the $A C$ is essential to ensure the effectiveness of corporate governance mechanisms through four main characteristics (independence, number of meetings, size, and financial expertise) (Bronson et al., 2009; Bedard et al., 2004). Similarly, the Jordanian Code of Corporate Governance provides that the $A C$ must have the following best practices: (1) should have at least three members, two of whom are required to be independent; (2) all members should possess some level of financial knowledge and one of them, at least, should be a financial expert or a member of accounting association or professional body; (3) members are to hold regular meetings with due notice of issues that will be considered; and (4) the committee is expected to have a minimum of four meetings in a year (Article 15 JSC, 2009).

\section{Literature review and hypotheses development}

\subsection{Literature review}

The general conception in agency theory is that a relationship exists between the principal (owner) and agent (manager), in which the owner delegates his work to his agent (Fama, 1980). The theory suggests that the agent will be motivated by self-interest rather than the desire to promote the interest of the principal. This is the source of the agency problem, where it demonstrates the conflict of interests among the two parties.

In a situation where conflict of interest arises among managers and shareholders, decisions are commonly taken by the managers. These decisions, according to Solomon (2004), are generally in the best interest of managers and not in that of the shareholders. From the perspective of agency theory therefore, the possibility of managers engaging in EM is high. The agency theory suggests a good mechanism to decrease EM by establishing a suitable committee and an appropriate board of directors as essential corporate governance mechanisms.

An AC is a mechanism of reducing this agency problem because an effective and efficient $A C$ can improve the credibility and quality of the annual audited accounts, and can assist the board of directors' 
work, which has to do with advancing and safeguarding the shareholders' interests (Alchain and Demsetz, 1972; Fama and Jensen, 1983). Their independent judgment could have an impact in ensuring that the financial information is transparent and not misleading. Beasley et al. (2010) revealed that AC members seek to ensure the effectiveness in the disclosure process rather than just serving on a ceremonial AC, which aligns with the position of the agency theory.

Researchers have investigated REM comprehensively through real activities. There exist three kinds of manipulation regarding real activity: (1) cash flow through operations; (2) reducing the expenses that are discretionary; and (3) production cost. Manipulation of cash flow is the effort of the managers to maximize the revenue and sales, so that profit can be achieved during the year. Multiple strategies can be adopted by managers to boost the sales by offering soft credit terms and discounted prices on a limited basis. Consequently, during the year, higher income is generated as sales are increased. However, as discounts are offered, credit sales and lenient contract conditions reduce the cash flow (Roychowdhury, 2006).

The second method proposed by Roychowdhury (2006) to detect REM in companies is using discretionary expenses as corporate managers may utilize expenses at discretion, bordering on expenses being considered as general, administrative and selling expenses; advertising expenses; and the expenses on research and development (R\&D), with the aim to attain short-term reported earnings. The third model of REM is using production cost, for services institutions, the production cost is solely based on cost of goods sold. The corporate manager tends to use production cost to manage short-term reported earnings through cost suppressing-related activities or expenses to inflate revenues or decrease expenses, which can enhance present period earnings. In this study, REM is adopted as a substitute for EM for the following reasons. First, executive managers show an intention of altering real activities of the organization to achieve their targets, even when the manipulations tend to reduce the value of the organization (Roychowdhury, 2006). Second, according to the researcher's knowledge, there seems to be limited studies that have employed the real activities manipulation method in Jordan as a substitute for EM.

\subsection{Hypotheses development}

AC Size and REM

The size of audit committee in terms of the number of the serving members is considered as a sign of the available resources for the effectiveness of the audit committee. As argued by Bedard et al. (2004), the bigger the AC, the higher the chance of uncovering and resolving possible problems that may arise in the process of financial reporting. This is because the size has a tendency of providing the necessary synergy and diversity of expertise and views to ensure a monitoring that is effective and efficient. The minimum number of audit committee members suggested by the Jordan Corporate Governance Code is three directors (ASE, 2009). There are inconsistent findings in previous research regarding REM and AC size. For example, according to Alhaddad et al. (2011); Madi et al. (2014); and Supriyaninsih and Faud (2016), positive link exists between AC size and REM. Similarly, a significant impact of AC size on earnings manipulation and earnings quality was reported by Azzoz and Khamees (2016). However, a negative association was found between AC and quality of earnings in the study of Hamdan et al. (2013). Another study has also revealed a negative association between earnings manipulation and AC size (Inaam and Khamoussi, 2016).

However, to guarantee effective monitoring, a large variety of skills, experiences, expertise and views can be enabled by a larger AC. In turn, potential issues in the procedure of corporate reporting are exposed and resolved as well. Therefore, AC size is the central part of AC characteristics. So, the following proposition is postulated:

$H_{1}$ : Audit committee size is negatively related to Real Earnings Management in the listed industrial and services firms in Jordan.

\section{AC Independence and REM}

Financial reporting monitoring is facilitated by $A C$ independence. To lessen $E M$, it is one of the critical deterring factors (Klein, 2002). Through the improvement of AC independence, there can occur enhancement in the monitoring function performed by the board of directors on the authority of equity 
shareholders. Researchers have claimed that for the external and internal auditors, an independent AC can be a reinforcing factor (Deli and Gillan, 2000).

As mentioned in the agency theory, the independence of directors of the AC plays an integral role in successfully monitoring management behavior (Fama and Jensen, 1983). It has been highlighted that there is no personal link to management or any other economic benefit of an independent AC. Moreover, as argued by Bedard and Gendron (2010), it is more likely that independent AC members will independently and objectively without the influence of management. A relationship has been reported between EM and AC independence. But findings of many studies are inconsistent. Some studies have reported that EM practices are mitigated by AC independence (Saleh et al., 2007; Klein, 2002). Worthy of mentioning are the studies by Talbi (2015); and Hassan and Ibrahim (2014), which have also reported that REM could be mitigated by AC independence, and which aligns with the findings of this study. However, studies have also indicated that a financial statement quality reduction could be due to the increasing number of constituted independent directors in the AC (Madi et al., 2014). A few other studies, like Peasnell et al. (2001); and Rahman and Ali (2006), have reported an insignificant link between EM and AC independence.

Arising from the postulation of the agency theory and the above discussion, an independent AC could offer a balanced evaluation and effective monitoring function. Thus, it can be posited that an AC comprising a larger proportion of independent directors can effectively reduce earnings manipulation. Hence, this study hypothesizes as follows:

$\mathrm{H}_{2}$ : Audit committee independence negatively relates to Real Earnings Management in the listed industrial and services firms in Jordan.

\section{AC Expertise and REM}

The $A C$, on its own, is not sufficient for enhancing the monitoring of companies, except if the members of the AC are not only independent but also have expertise in certain fields (Sahlan, 2011). Studies have shown that AC members with expertise, professional certificates and higher education, experience and skills in accounting and financial matter, can impact EM (Hamdan et al., 2013). Empirical findings and results from previous studies have substantially demonstrated a negative relationship between EM and AC expertise (Inaam and Khamoussi, 2016; Puat and Susela, 2013). Similarly, in studies by Hassan and Ibrahim (2014); Al-Zoubi and Selamat (2012); and Puat and Susela (2013), the findings reveal show that there is a negative relationship between the expertise of the members of AC and REM. Thus, it indicates that expertise of AC members might decrease REM. Nevertheless, Mohamad et al. (2012) posited that inclusion of individuals with financial expertise as AC members, can still lead to a soar in EM practices.

However, Dhaliwal et al. (2010) stated that effective monitoring of corporate reporting process requires financial experts to be part of the AC. Such expert members can better interpret and comprehend the financial statement. AC members who have expertise in finance can ask the right questions and challenge the management as well as the external auditors toward a better level of financial reporting quality (Bedard and Gendron, 2010). As a result, there will be transparency in corporate reporting. Therefore, agency problems are mitigated which are associated with the flow of information.

On the basis of the above argument, there should be appropriate knowledge and experience among the members of the AC, especially in auditing and accounting. By possessing this expertise, firm performance can be improved through the evaluation of the AC. Additionally, monitoring ability can be improved by the expertise of the AC members. As a result, the quality of the financial report increases and EM practices prevented. Hence, the following assumption is derived:

$H_{3}$ : Audit committee expertise negatively relates to Real Earnings Management in the listed industrial and services firms in Jordan.

\section{AC Meetings and REM}

AC expertise and independence cannot on their own, lead to effectiveness, except with an active committee (Bedard et al., 2004). The frequency of AC meetings is significant in helping the management to resolve any conflicting issue and enhance the internal control system in firms (Stewart and Lois, 2007). Several studies have demonstrated the existence of a relationship between EM and AC meetings, but the findings in these studies are inconsistent and inconclusive. 
Thoopsamut and Jaikengkit (2009) reported a minor association between AC activity and EM; while Saleh et al. (2007); and Abdul Rahman et al. (2006), demonstrated a significant and positive link between AC meetings and EM. But, the findings of a majority of studies across diverse contexts (Bedard et al., 2004; Baxter et al., 2009; Davidson et al., 2005; Inaam and Khamoussi, 2016) have indicated a negative association between AC meetings and EM. Regular AC meetings, which represent the degree of assiduousness and scrutiny of committee members, demand AC members to be proactive and inquisitive about the financial reporting process (Turner, 2001). Regular committee meetings can precipitate high quality of reporting system. Therefore, a proactive $A C$ which is involved in frequent meetings has the capability to reduce REM.

Based on the foregoing argument, frequent AC meetings could be said to be a prerequisite for effective monitoring. This is because if the $A C$ arranges regular meetings, it could enable the committee to supervise the company management properly and detect REM. Hence, the following is hypothesized:

$\mathrm{H}_{4}$ : Audit committee meetings negatively relate to Real Earnings Management in the listed industrial and services firms in Jordan.

\section{Methodology of research}

\subsection{Population and sample}

The unit of analysis is firms registered on the Amman Stock Exchange (ASE). The Jordanian Code of Corporate Governance and the Jordanian Listing Requirements are the standards which govern the mentioned companies. Companies listed on the ASE are categorized into three sectors, i.e., the financial sector, the industrial sector and the services sector. In the current study, services and industrial firms listed on the ASE encompass the 2011 to 2017 period in addition to 2010 for calculation of the changes in sales. The choice of the timeframe is due to the fact that the Corporate Governance Code in Jordan has already been implemented in September 2009 and 2017 is the latest year of data. The financial sector is not included because it has distinct and different regulations related to financial reports, and comes under the Insurance Commission and the Jordan Central Bank. Data was obtained from the annual reports of both services and industrial firms, from the website of the ASE, from the firms' website or through statistical bulletins/Securities Depository Center website.

Table 1. Description of Sample

\begin{tabular}{|c|c|}
\hline Sector & Number of firms \\
\hline Industry & 63 \\
\hline Services & 54 \\
\hline Total & 117 \\
\hline Unavailable data & (14) \\
\hline Final sample & 103 \\
\hline Final study observations ( $103 * 7$ years) & 721 \\
\hline
\end{tabular}

\subsection{Research Model}

The constituents of the dependent variable of this study involve a combination of abnormal cash flow from operations, abnormal discretionary expenses and abnormal cost of goods sold, as a potential measurement of REM. The independent variable for the research is AC characteristics. Hence, a functional form of the equation was generated for this study as in the following equation.

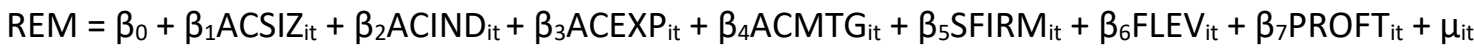

Where:

REM = Real Earnings Management; ACSIZ = AC Size; ACIND =AC Independence; ACEXP = AC Expertise; ACMTG = AC Meeting; SFIRM = Firm Size; FLEV = Firm Leverage; PROFT = Firm Profitability; It $=$ Panel indictor for $i=$ Firm, $\mathrm{t}=$ Time; $\mu=$ Error term.

\subsection{REM Measurement}


This study measured REM using three proxies (abnormal cash flow, abnormal discretionary expenses and abnormal COGS). Estimating for normal level of each of the proxies was derived by using the coefficient from the regression of each of the variables in each equation, consistent with prior studies (Kang and Kim, 2012; Hashemi and Rabiee, 2011; Cohen and Zarowin, 2010; Visvanathan, 2008; Roychowdhury, 2006). For the estimated CFO (ECFO), Model 1 was established as suggested by Roychowdhury (2006). The formula for cash flow from operation activities is as below:

$C F O_{t} / A_{t-1}=\alpha_{0}+\alpha_{1}\left(1 / A_{t-1}\right)+B_{1}\left(S_{t} / A_{t-1}\right)+B_{2}\left(\Delta S / A_{t-1}\right)+\varepsilon_{t}$

(Model 1)

Where:

$\mathrm{CFO}_{t}=$ cash flow from operation activities of year $t$

$A_{\mathrm{t}-1}=$ Total assets at the beginning of year $t$

$\alpha_{0}=$ Constant or Intercept

$\mathrm{S}_{\mathrm{t}}=$ Sales during year $t$

$\Delta S=$ Change in sales from year $t-1$ to $t$

$\varepsilon_{\mathrm{t}}=$ Error term

The variance between actual cash flow from operations (ACFO) and estimated cash flow (ECFO) from operating activities is known as abnormal cash flow from operations (AbCFO) as stated below:

\section{$A b C F O=A C F O-E C F O$}

Where:

AbCFO = Abnormal cash flow from operations

ACFO $=$ Actual cash flow from operations

$\mathrm{ECFO}=$ Estimated cash flow from operations

The second technique proposed by Roychowdhury (2006) that can be employed to detect EM in companies is using discretionary expenses as corporate managers may utilize expenses at discretion, bordering on advertising expenses, selling, administrative and general expenses, and the expenses on R\&D, with the goal of attaining short-term reported earnings. Thus, the formula for actual discretionary expenses is as below:

$A D C=R \& D+A D V+S A G$

Where:

$A D C=$ Actual discretionary expenses

$R \& D=$ Research and development

$A D V=$ Advertising expenses

SAG = Selling, administrative and general expenses

The estimated discretionary expenses (EDC) is expressed in Model 2 as follows:

$D C_{t} / A_{t-1}=\alpha_{0}+\alpha_{1}\left(1 / A_{t-1}\right)+B\left(S_{t-1} / A_{t-1}\right)+\varepsilon_{i}$

(Model 2)

Where:

$D C_{\mathrm{t}}=$ discretionary expenses in year $t$

$A_{t-1}=$ Total Assets at the beginning of year $t$

$\mathrm{S}_{\mathrm{t}}=$ Sales during year $t$

$\varepsilon_{\mathrm{t}}=$ Error term

The difference between actual discretionary expenses and estimated discretionary expenses is known as abnormal discretionary expenses. The formula is expressed as below:

$A b D C=A D C-E D C$

Where:

$\mathrm{AbDC}=$ Abnormal discretionary expenses

$A D C=$ Actual discretionary expenses 
$E D C=$ Estimated discretionary expenses

The third model of REM is using production cost. For services institutions, the production cost is solely based on cost of goods sold. The corporate manager tends to use production cost to manage shortterm reported earnings through cost suppressing-related activities or expenses to inflate revenues or decrease expenses, which can enhance present period earnings. Therefore:

ACOGS $=$ REV - GP

Where:

ACOGS $=$ actual cost of goods sold

$\mathrm{REV}=$ revenue

$\mathrm{GP}=$ gross profit

Estimated COGS (ECOGS) is calculated in Model 3 as:

ECOGSt $/ A t-1=\alpha 0+\alpha 1(1 / A t-1)+B(S t-1 / A t-1)+\varepsilon t$

(Model 3)

Where:

ECOGSt $=$ estimated cost of goods sold in year $t$

At-1 $=$ Total Assets at the beginning of year $t$

St $=$ Sales during year $t$

$\varepsilon \mathrm{t}=$ Error term

The difference between ACOGS and ECOGS is known as abnormal cost of goods sold. The formula is expressed as below:

$A b C O G S=A C O G S-E C O G S$

Where:

AbCOGS $=$ Abnormal cost of goods sold

ACOGS = Actual cost of goods sold

ECOGS $=$ Estimated cost of goods sold

Therefore, REM formula is finally expressed as:

$R E M=A b C F O+A b D C+A b C O G S$

Where:

REM = Real Earnings Management

$\mathrm{AbCFO}=$ Abnormal cash flow from operations

$\mathrm{AbDC}=\mathrm{Abnormal}$ discretionary expenses

AbCOGS = Abnormal cost of goods sold

\subsection{Independent variables measurement}

In the present study, AC meetings, expertise, independence and size are the AC characteristics used as independent variables. Table 2 indicates the way four variables of the AC are defined and measured.

Table 2. Measurement of the Independent Variables

\begin{tabular}{|c|c|c|}
\hline Var & Measurement & Reference \\
\hline $\begin{array}{l}\text { Audit Committee Size } \\
\text { (ACSIZ) }\end{array}$ & $\begin{array}{l}\text { Total number of directors occupying the AC of a firm's } \\
\text { corporate board at the end of the financial year }\end{array}$ & $\begin{array}{c}\text { (Kang \& Kim, 2012; Saleh et } \\
\text { al., 2007) }\end{array}$ \\
\hline $\begin{array}{c}\text { Audit Committee } \\
\text { Independence (ACIND) }\end{array}$ & $\begin{array}{l}\begin{array}{l}\text { Number of non-executive directors as part of total AC } \\
\text { members }\end{array}\end{array}$ & $\begin{array}{l}\text { (Al-Rassas \& Kamardin, 2015; } \\
\text { Abdul Rahman \& Ali, 2006) }\end{array}$ \\
\hline $\begin{array}{l}\text { Audit Committee } \\
\text { Expertise (ACEXP) }\end{array}$ & $\begin{array}{l}\text { Number of } \mathrm{AC} \text { members who possess financial and } \\
\text { accounting experiences and/or certifications at the end of } \\
\text { financial year. }\end{array}$ & $\begin{array}{c}\text { (Othman et al., 2014; } \\
\text { Akhtaruddin \& Haron, 2010) }\end{array}$ \\
\hline Audit Committee & The number of $A C$ meetings held in a year. & (Habbash, 2010; Xie et al., \\
\hline
\end{tabular}




\begin{tabular}{ccc}
\hline Var & Measurement & Reference \\
\hline Meeting (ACMTG) & $2003)$
\end{tabular}

\subsection{Measurement of the Control Variables (Firm Attributes)}

Three variables were added, namely firm profitability, leverage and firm size to study the association between the AC characteristics and REM. The purpose to add variables is to control the factors that influence the incentives of management to practice REM. Table 3 shows the measurement and definitions of control variables.

Table 3. Measurement of the Control Variables (Firm Attributes)

\begin{tabular}{|c|c|c|}
\hline Variables & Measurement & Reference \\
\hline $\begin{array}{l}\text { Firm Size } \\
\text { (SFIRM) }\end{array}$ & $\begin{array}{l}\text { Total assets at the end of the } \\
\text { financial year. }\end{array}$ & (Akle, 2011; Afify, 2009; Alsaeed, 2006; Ismail \& Chandler, \\
\hline $\begin{array}{l}\text { Profitability } \\
\text { (PROFT) }\end{array}$ & $\begin{array}{l}\text { Ratio of profit after tax to total } \\
\text { assets of the company at the end } \\
\text { of the financial year. }\end{array}$ & $\begin{array}{l}\text { (Munisi \& Randoy, 2013; Hashem et al., 2012; Garay \& } \\
\text { Gonzalez, 2008; Akhtaruddin, 2005; Yermack, 1996) }\end{array}$ \\
\hline $\begin{array}{l}\text { Firm Leverage } \\
\quad \text { (FLEV) }\end{array}$ & $\begin{array}{l}\text { Ratio of total debt to total assets } \\
\text { of the company at the end of the } \\
\text { financial year. }\end{array}$ & $\begin{array}{l}\text { (Tsagem et al., 2015; Liu \& Tsai, 2015; Kanagaretnam et al., } \\
\text { 2014; Ahmad et al., 2013; Benkel, Mather, \& Ramsay, 2006) }\end{array}$ \\
\hline
\end{tabular}

\section{Empirical results}

\subsection{Descriptive analysis}

The descriptive results of REM, four characteristics of the $A C$ and firm attributes are presented in Table 4. The average of REM in the listed industrial and services firms in Jordan is -0.033 . The maximum value of REM is 3.320 and minimum value is -3.770 . Moreover, the AC size ranges from two to seven. On average (mean), the companies appoint three persons as AC members. For AC independence, Table 4 shows on average, that about $81.55 \%$ non-executive directors are in the AC. The maximum and minimum values range from 0 and 1 ; the minimum value of 0 indicates that there are ACs that do not have independent directors. For AC expertise and experience, the mean (1.86) in Table 4 shows that about two members of the committee have the required experience and expertise with maximum value of five and minimum value of zero. However, the Code of Corporate Governance in Jordan stipulates that listed companies should include in their AC at least one member with accounting certification or financial expertise. This infers that many Jordanian firms comply with the Jordanian Code of Corporate Governance regarding expertise requirements. Table 4 shows a maximum of 10 meetings and an average of four meetings of the AC in a year. This finding shows that most firms based in Jordan are working according to the Jordanian Code of Corporate Governance, where according to this Code; it is recommended that the AC should meet at least four times yearly.

\begin{tabular}{lccccc}
\hline \multicolumn{1}{c}{ Var. } & $\mathbf{N}$ & Min & Max & Mean & Std. Dev. \\
\hline REM & 721 & -3.770 & 3.320 & -0.033 & 0.3646 \\
ACSIZ & 721 & 2 & 7 & 3.3143 & 0.7225 \\
ACIND & 721 & 0 & 1 & 0.8155 & 0.2794 \\
ACEXP & 721 & 0 & 5 & 1.8585 & 1.1239 \\
ACMTG & 721 & 1 & 10 & 4.4956 & 1.3500 \\
SFIRM (Log.) & 721 & 2.504 & 9.853 & 7.5460 & 0.7616 \\
FLEV & 721 & 0.001 & 0.896 & 0.3440 & 0.2282 \\
PROFT & 721 & -0.7299 & 0.7127 & 0.0171 & 0.1137 \\
\hline
\end{tabular}

ACSIZ = Total number of AC members, $\mathbf{A C I N D}=$ AC independence $\mathbf{A C E X P}=\mathrm{AC}$ financial expertise, $\mathbf{A C M T G}=$ Number of $A C$ meetings held during the financial year, REM= real earnings management, SFIRM (Log.)= Natural logarithm of company size measured by 
total assets, FLEV= leverage ratio of total debts to total assets, PROFT= ratio of total profit to total assets

Table 4.Descriptive Statistics of Independent, Dependent and Control Variables

In relation to the control variables, the average company size, as measured by natural log of the total assets of the firm is 7.546. This ratio is similar to Azzoz and Khamees (2016) who reported that the mean of the Jordanian firms' size is 7.67. Furthermore, it appears that the average leverage is $34.4 \%$, with the minimum value of $0.1 \%$ and the maximum value of $89.6 \%$. The average leverage is similar to the ratio found by Aldaoud (2015), who reported that the mean of leverage in Jordanian listed companies is $34.3 \%$. Table 4 demonstrates that mean value of firm profitability is about $2 \%$ with minimum and maximum ratio, as measured by the ratio of net income to total assets, at $-73 \%$ and $71 \%$, respectively.

\subsection{Correlation analysis}

Table 5 displays the coefficients of Pearson correlation between the variables of the current study. The multicollinearity test was conducted using Pearson correlation in order to find the high correlation among all independent variables. As mentioned by researchers, if the correlation coefficient is more than 0.90, it indicates the problem of multicollinearity (Hair et al., 2010; Tabachnick and Fidell, 2007). The result as in Table 5 shows that the values of all correlation coefficients are below 0.90 . This shows that there is no problem of multicollinearity among variables used in the present study.

Table 5. Pearson correlation

\begin{tabular}{l|ccccccc}
\hline \multicolumn{1}{c}{ ACSIZE } & ACIND & ACEXP & ACMTG & SFIRM & FLEV & PROFT \\
\hline ACSIZE & 1 & & & & & & \\
ACIND & $-0.192^{* *}$ & 1 & & & & & \\
ACEXP & $0.148^{* *}$ & $0.421^{* *}$ & 1 & & & & \\
ACMTG & 0.036 & $0.268^{* *}$ & $0.242^{* *}$ & 1 & & & \\
SFIRM & $0.332^{* *}$ & $-0.105^{* *}$ & -0.008 & $-0.138^{* *}$ & 1 & & \\
FLEV & $0.110^{* *}$ & $-0.168^{* *}$ & $-0.119^{* *}$ & -0.050 & $0.224^{* *}$ & 1 & \\
PROFT & $0.10^{* *}$ & $-0.118^{* *}$ & $-0.065^{*}$ & $-0.094^{* *}$ & $0.168^{* *}$ & $-0.276^{* *}$ & 1 \\
\hline
\end{tabular}

**. 0.01 significance level of correlation (2-tailed). *. 0.05 significance level of correlation (2-tailed).

\subsection{Regression Analysis and Hypotheses Testing}

As evidenced in Table 6, the regression analysis reveals that the $\mathrm{R}^{2}$ for the model is $28.2 \%$; which indicates that the independent variables explain $28.2 \%$ of the variance in REM. Moreover, the model is significant (Fstatistic $=39.956, p<0.000$ ), indicating that the model significantly explains the difference in REM among

Table 6. Summary of Regressions Analysis

\begin{tabular}{|c|c|c|c|c|c|}
\hline Variables & Hypothesis & Beta & Std. Error & $\mathrm{t}$ & Sig. \\
\hline (Constant) & & 2.070 & 0.134 & 15.399 & $0.000^{* * *}$ \\
\hline ACSIZE & $\mathrm{H}_{1}$ & 0.013 & 0.018 & 0.696 & 0.487 \\
\hline ACIND & $\mathrm{H}_{2}$ & -0.180 & 0.049 & -3.659 & $0.000^{* * *}$ \\
\hline ACEXP & $\mathrm{H}_{3}$ & -0.025 & 0.012 & -2.119 & $0.034 * *$ \\
\hline ACMTG & $\mathrm{H}_{4}$ & -0.072 & 0.009 & -7.931 & $0.000^{* * *}$ \\
\hline SFIRM & & -0.214 & 0.017 & -12.592 & $0.000^{* * *}$ \\
\hline FLEV & & 0.048 & 0.056 & 0.852 & 0.394 \\
\hline PROFT & & 0.274 & 0.111 & 2.468 & $0.014^{* *}$ \\
\hline$R^{2}$ & 28.2 & & & & \\
\hline $\mathrm{F}$ & 39.956 & & & & \\
\hline Sig & 0.000 & & & & \\
\hline
\end{tabular}

$* * *, * *, *$ Significant at $1 \%, 5 \%$ and $10 \%$ levels, respectively.

Jordanian listed firms. Also in Table 6 , the outcome of the statistical result indicates that there is no association between AC size and REM. Specifically, the result shows that there is an insignificant but 
positive association between EM and $A C$ size $(\beta=-0.013$; $t$-value $=0.696 ; p$-value $=0.487)$. Thus, $\mathrm{H}_{1}$ is not supported.

This finding's implication is that REM is not influenced or affected by the size of the AC in the listed industrial and services firms in Jordan. The study's finding contradicts the argument of Vafeas (2005) that small AC will be unable to perform its functions excellently and efficiently. The finding of this study is consistent with Hamdan et al. (2013) which similarly found no association between AC size and discretionary accruals measured by the modified Jones model.

The result in Table 6 further reveals a negative significant link between AC independence and REM in the Jordanian listed industrial and services companies $(\beta=-0.180$; $t$-value $=-3.659, p$-value $=0.000$ ). Based on this, $\mathrm{H}_{2}$ is supported. This empirical result concurs with previous results of Azzoz and Khamees (2016); and Alzoubi (2016). This finding is similar to the agency theory proposition, suggesting that the autonomous members of the AC might decrease the practices of REM. The implication of this result is that autonomy of the members of the $A C$ and their activities are being separated from management influence. It can assist in preventing the issue of manipulation of financial statements and reporting of such statements in companies. Therefore, the company will be able to have efficient and effective internal control of financial reporting.

As proposed, Table 6 reveals a negatively significant relationship between AC expertise and REM ( $\beta=$ $-0.025 ; \mathrm{t}$-value $=-2.119 ; \mathrm{p}$-value $=0.034)$. Thus, greater expertise of $\mathrm{AC}$ leads to lesser manipulation of earnings. This finding is also consistent with earlier findings of Inaam and Khamoussi (2016); Hassan and Ibrahim (2014); Puat and Susela (2013); and Al-Zoubi and Selamat (2012), which all found the existence of significant negative association between the two constructs in different settings and contexts. This empirical finding suggests that AC expertise cannot be underestimated in curbing the incidence of REM. When the $A C$ members are equipped with accounting and financial knowledge, their accounting skills makes it very difficult for financial statements to be manipulated. This is because the monitoring power of the $A C$ is strong.

The regression result of this study as indicated in Table 6 shows that $A C$ meetings is the most influential factor of $A C$ characteristics that determine REM, with highest $t$-value $(t=-5.637)$. The statistical result clearly shows a negatively significant link between AC meetings and REM $(\beta=-0.060 ; p$-value $=0.000)$. Thus, it can be suggested that $A C$ meeting frequency is helpful for eliminating REM. The current finding is consistent with the earlier results of Alzoubi (2016) and Azzoz and Khamees (2016). From the Jordan perspective, the Jordanian Corporate Code states that the AC should meet at least four times in a year. This empirical study gives support for the Jordanian Corporate Code because the higher the number of meetings, the better the chances for the AC to prevent the incidence of REM.

Regarding control variables, the outcomes in Table 6 reveal a very strong and negatively significant relationship between REM and firm size $(\beta=-0.214 ; t$-value $=-12.592 ; p$-value $=0.000)$. This implies that the size of an organization has an influence on the ability to manipulate financial records and financial reporting. In other words, smaller companies tend to engage more in REM than large firms to evade reporting losses and exiting from the market.

The results reveal no significance between REM and firm leverage $(\beta=0.048 ; t$-value $=0.852 ; p$-value $=0.394)$. In other words, whether Jordanian firms have high or low debt proportion, it does not affect the earnings manipulation level. Furthermore, the result of the regression analysis indicates the presence of a positive association between profitability and $\operatorname{REM}(\beta=0.274$; $t$ and $p$ value $=2.468 ; 0.014$, respectively). It implies that the more the profit of the firm, the greater the chances of REM.

\section{Conclusions}

The impact of AC characteristics (size, independence, meetings and expertise) on REM is investigated in this study. A sample size of 721 firm-year observations is used in this research. The observations are from year 2011 to 2017 for each industrial and Services Company listed on the ASE. The major objective of this current research is to examine the association between REM and characteristics of the AC. This relationship is examined in the context of Jordan. The findings of this study indicate that AC meetings, independence 
and expertise have a significantly negative relationship with REM. As per the regression analysis results, there exists no relationship between REM and AC size.

The findings of the current study are important for policymakers and regulators for policy and strategy formulation in terms of credibility of financial reports in the Jordan context. For future research, it is recommended that studies may determine the outcome of AC characteristics on abnormal COGS, abnormal cash flow from operations or abnormal discretionary expenses separately. Additionally, other characteristics of the $\mathrm{AC}$ may be considered by researchers in future which may have an impact on REM. These characteristics may include remuneration of $A C$ members, ownership of the $A C$ members and $A C$ quality.

\section{References}

1. Rahman, A. R., \& Ali, H. M. F. (2006). Board, audit committee, culture and earnings management: Malaysian evidence. Managerial Auditing Journal, 21(7), 783-804.

2. Abdullatif, M. (2006). The effectiveness of audit committees in Jordanian public shareholding companies and potential company characteristics affecting it: perceptions from auditors in Jordan. Dirasat: Administrative Sciences, 33(2), 450-468.

3. Afify, H. A. E. (2009). Determinants of audit report lag: Does implementing corporate governance have any impact? Empirical evidence from Egypt. Journal of Applied Accounting Research, 10(1), 56-86.

4. Ahmed, S. (2013). Board of director characteristics and earnings management in Malaysia. In international conference on accounting and finance (AT). Proceedings (p. 208). Global Science and Technology Forum.

5. Akhtaruddin, M. (2005). Corporate mandatory disclosure practices in Bangladesh. The International Journal of Accounting, 40(4), 399-422.

6. Akhtaruddin, M., \& Haron, H. (2010). Board ownership, audit committees' effectiveness and corporate voluntary disclosures. Asian Review of Accounting, 18(1), 68-82.

7. Akle, Y. H. (2011). The Relationship Between Financial Reporting Timeliness And Attributes of Companies Listed On Egyptian Stock Exchange" An Empirical Study.". Internal Auditing \& Risk Management, 6(3), 83-103

8. Alchian, A. A., \& Demsetz, H. (1972). Production, information costs, and economic organization. The American economic review, 62(5), 777-795.

9. Aldaoud, K. A. (2015). The influence of corporate governance and ownership concentration on the timeliness of financial reporting in Jordan (Doctoral dissertation, University Utara Malaysia).

10.Al-Haddad, W., Alzurqan, S. T., \& Al-Sufy, F. J. (2011). The effect of corporate governance on the performance of Jordanian industrial companies: An empirical study on Amman Stock Exchange. International Journal of Humanities and Social Science, 1(4), 55-69.

11.Al-Rassas, A. H., \& Kamardin, H. (2015). Directors' independence, internal audit function, ownership concentration and earnings quality in Malaysia. Asian Social Science, 11(15), 244.

12.Alsaeed, K. (2006). The association between firm-specific characteristics and disclosure: The case of Saudi Arabia. Managerial Auditing Journal, 21(5), 476-496.

13.Alzoubi, E. S. S., \& Selamat, M. H. (2012). The effectiveness of corporate governance mechanisms on constraining earning management: Literature review and proposed framework. International Journal of Global Business, 5(1), 17-35.

14.Alzoubi, E. S. S., (2016). Ownership structure and earnings management: evidence from Jordan. International Journal of Accounting \& Information Management, 24(2), 135-161.

15.ASE. (2009). Amman Stock Exchange. Retrieved from: http://www.ase.com.jo/pages.php? menu_id=119\&local_type $=0 \&$ local_id=0\&local_details $=0$.

16.Azzoz, A. R. A. M., \& Khamees, B. A. (2016). The Impact of Corporate Governance Characteristics on Earnings Quality and Earnings Management: Evidence from Jordan. Jordan journal of business administration, 12(1), 187-207.

17.Baxter, P., \& Cotter, J. (2009). Audit committees and earnings quality. Accounting \& Finance, 49(2), 267-290. 
18.Beasley, M. S., Carcello, J. V., Hermanson, D. R., \& Neal, T. L. (2010). The audit committee oversight process. Contemporary Accounting Research, 26(1), 65-122.

19.Bédard, J., \& Gendron, Y. (2010). Strengthening the financial reporting system: Can audit committees deliver? International journal of auditing, 14(2), 174-210.

20.Bedard, J., Chtourou, S. M., \& Courteau, L. (2004). The effect of audit committee expertise, independence, and activity on aggressive earnings management. Auditing: A Journal of Practice \& Theory, 23(2), 13-35.

21.Benkel, M., Mather, P., \& Ramsay, A. (2006). The association between corporate governance and earnings management: The role of independent directors. Corporate Ownership \& Control, 3(4), 65-75.

22.Bhasin, M. L. (2012). Audit committee scenario and trends in a developing country. School of Doctoral Studies European Union Journal, 4, 53-70.

23.Bronson, S. N., Carcello, J. V., Hollingsworth, C. W., \& Neal, T. L. (2009). Are fully independent audit committees really necessary? Journal of Accounting and Public Policy, 28(4), 265-280.

24. Cadbury Committee (1992). Report of the Committee on the Financial Aspects of Corporate Governance. Gee Publishing, London.

25.Chi, W., Lisic, L. L., \& Pevzner, M. (2011). Is enhanced audit quality associated with greater real earnings management? Accounting Horizons, 25(2), 315-335.

26.Cohen, D. A., \& Zarowin, P. (2010). Accrual-based and real earnings management activities around seasoned equity offerings. Journal of accounting and Economics, 50(1), 2-19.

27.Cohen, D. A., Dey, A., \& Lys, T. Z. (2008). Real and accrual-based earnings management in the preand post-Sarbanes-Oxley periods. The accounting review, 83(3), 757-787.

28. Davidson, R., Goodwin-Stewart, J., \& Kent, P. (2005). Internal governance structures and earnings management. Accounting \& Finance, 45(2), 241-267.

29.Dechow, P. M., \& Skinner, D. J. (2000). Earnings management: Reconciling the views of accounting academics, practitioners, and regulators. Accounting horizons, 14(2), 235-250.

30.Deli, D. N., \& Gillan, S. L. (2000). On the demand for independent and active audit committees. Journal of corporate finance, 6(4), 427-445.

31.Dhaliwal, D. A. N., Naiker, V. I. C., \& Navissi, F. (2010). The association between accruals quality and the characteristics of accounting experts and mix of expertise on audit committees. Contemporary Accounting Research, 27(3), 787-827.

32.Enomoto, M., Kimura, F., \& Yamaguchi, T. (2015). Accrual-based and real earnings management: An international comparison for investor protection. Journal of Contemporary Accounting \& Economics, 11(3), 183-198.

33.Fama, E. F. (1980). Agency Problems and the Theory of the Firm. Journal of political economy, 88(2), 288-307.

34.Fama, E. F., \& Jensen, M. C. (1983). Agency problems and residual claims. The Journal of Law and Economics, 26(2), 327-349.

35.Fan, H. (2017). Earnings Management, Politically Connected CEOs, and Politically Connected Independent Board Members: Evidence from China. International Journal of Accounting and Financial Reporting, 7(1), 291-310.

36.Garay, U., \& González, M. (2008). Corporate governance and firm value: The case of Venezuela. Corporate Governance: An International Review, 16(3), 194-209.

37.Gunny, K. A. (2005). What are the consequences of real earnings management? Working paper. Haas School of Business, University of California, Berkeley CA 94720

38.Habbash, M. (2010). The effectiveness of corporate governance and external audit on constraining earnings management practice in the UK (Doctoral dissertation, Durham University).

39.Hair, J. F., Black, W. C., Babin, B. J., Anderson, R. E., \& Latham, R. (2010). Multivariate data analysis (7th ed). New Jersey: Pearson3.

40. Hamdan, A. M., Mushtaha, S., \& Musleh Al-Sartawi, A. (2013). The audit committee characteristics and earnings quality: Evidence from Jordan. Australasian Accounting Business and Finance Journal, 7(4). 
41.Hashem, N., Bahman, B., \& Azam, S. (2012). An Empirical Analysis of Earnings Management Motives in Firms Listed on Tehran Stock Exchange. Journal of Basic and Applied Scientific Research, Res., 2(10) 9990, 9993.

42.Hashemi, S. A., \& Rabiee, H. (2011). The relation between real earnings management and accounting earnings management: evidence from Iran. Business and Management Review, 1(8), 25-33.

43.Hassan, S. U., \& Ibrahim, G. (2014). Governance Attributes and Real Activities Manipulation of Listed Manufacturing Firms in Nigeria. International Journal of Accounting and Taxation, 2(1), 37-62.

44.Healy, P. M., \& Wahlen, J. M. (1998). A review of the earnings management literature and its implications for standard setting. Accounting horizons, 13(4), 365-383.

45.Inaam, Z., \& Khamoussi, H. (2016). Audit committee effectiveness, audit quality and earnings management: a meta-analysis. International Journal of Law and Management, 58(2), 179-196.

46.Ismail, K. N. I. K., \& Chandler, R. (2003). Perceptions of professional investors in Malaysia on the usefulness of quarterly financial reports. Jurnal Pengurusan (UKM Journal of Management), 24(2005), 105124.

47.JSC, Jordanian Securities Commission. (2009). Corporate governance code for shareholding companies listed on Amman Stock Exchange. 1-16. Retrieved from http://www.sdc.com.jo/arabic/images/ stories/pdf/corporate governance companies.pdf

48.Kamel, H. (2012). Earnings management and initial public offerings: a new perspective from Egypt. Journal of Accounting in Emerging Economies, 2(2), 96-118.

49.Kanagaretnam, K., Lim, C. Y., \& Lobo, G. J. (2014). Effects of international institutional factors on earnings quality of banks. Journal of Banking \& Finance, 39(February), 87-106.

50.Kang, S. A., \& Kim, Y. S. (2012). Effect of corporate governance on real activity-based earnings management: Evidence from Korea. Journal of Business Economics and Management, 13(1), 29-52.

51.Kim, J. and Park, M. (2014), "Real activities manipulation and auditors client retention decisions", The Accounting Review, Vol. 89 No. 1, pp. 367-401.

52.Kim, J. and Sohn, B. (2013), "Real earnings management and cost of capital", Journal of Accounting Public Policy, Vol. 32 No. 6, pp. 518-543.

53.Klein, A. (2002), "Economic determinants of audit committee independence", Accounting Review, Vol. 77 No. 2, pp. 435-52.

54.Liu, J. L., \& Tsai, C. C. (2015). Board Member Characteristics and Ownership Structure Impacts on Real Earnings Management: Evidence from Taiwan. Accounting and Finance Research, 4(4), 84-96.

55.Madi, H. K., Ishak, Z., \& Manaf, N. A. A. (2014). The impact of audit committee characteristics on corporate voluntary disclosure. Procedia-Social and Behavioral Sciences, 164, 486-492.

56. Mohamad, M., Majdi Abdul Rashid, H., \& Mohammed Shawtari, F. A. (2012). Corporate governance and earnings management in Malaysian government linked companies: The impact of GLCs' transformation policy. Asian Review of Accounting, 20(3), 241-258.

57.Munisi, G., \& Randøy, T. (2013). Corporate governance and company performance across SubSaharan African countries. Journal of Economics and Business, 70, 92-110.

58.Othman, R., Ishak, I. F., Arif, S. M. M., \& Abdul, N. (2014). Influence of audit committee characteristics on voluntary ethics disclosure. Procedia - Social and Behavioral Sciences, 145, 330-342.

59.Pacheco Paredes, A. A., \& Wheatley, C. (2017). The influence of culture on real earnings management. International Journal of Emerging Markets, 12(1), 38-57.

60.Pae, S. S., \& Quinn, T. (2011). Do firms manipulate earnings when entering the bond market? Academy of Accounting and Financial Studies Journal, 15(1), 99-115.

61.Peasnell, K. V., Pope, P. F., \& Young, S. (2001). The characteristics of firms subject to adverse rulings by the Financial Reporting Review Panel. Accounting and Business Research, 31(4), 291-311.

62.Puat Nelson, S., \& Devi, S. (2013). Audit committee experts and earnings quality. Corporate Governance: The international journal of business in society, 13(4), 335-351.

63. Roychowdhury, S. (2006). Earnings management through real activities manipulation. Journal of accounting and economics, 42(3), 335-370. 
64.Sahlan, L. A. (2010). The Malaysian listing requirement reforms and earnings management practices of public listed firms. Retrieved from https://ssrn.com/abstract=1635115 or http://dx.doi.org/10.2139/ssrn.1635115.

65.Saleh, N., Mohd Iskandar, T., \& Mohid Rahmat, M. (2007). Audit committee characteristics and earnings management: Evidence from Malaysia. Asian Review of Accounting, 15(2), 147-163.

66.Solomon, J., \& Solomon, A. (2004). Corporate governance and accountability. John Wiley, New York. NY. Retrieved from http://www.untag-smd.ac.id/files/Perpustakaan_Digital_1/CORPORATE\% 20GOVERNANCE\%20Corporate\%20Governance\%20and\%20Accountability.pdf

67.Stewart, J., \& Munro, L. (2007). The impact of audit committee existence and audit committee meeting frequency on the external audit: Perceptions of Australian auditors. International Journal of Auditing, 11(1), 51-69.

68.Supriyaningsih, S., \& Fuad, F. (2016). The Influence of Audit Committee Characteristics on Real Earnings Management. Jurnal Akuntansi dan Auditing, 13(1), 61-79.

69.Tabachnick, B.G. \& Fidell, L.S (2007). Using multivariate statistics (5th ed). Boston: Pearson Education.

70.Talbi, D., Omri, M. A., Guesmi, K., \& Ftiti, Z. (2015). The Role of Board Characteristics in Mitigating Management Opportunism: The Case of Real Earnings Management. Journal of Applied Business Research, 31(2), 661-674.

71.Thoopsamut, W., \& Jaikengkit, A. O. (2009). Audit Committee Characteristics; Audit Firm Size and Quarterly Earnings Management in Thailand. In Emerging Issues and Challenges in Business \& Economics: Selected Contributions from the 8th Global Conference. 24(October), 47-70. Firenze University Press.

72.Tsagem, M. M., Aripin, N., \& Ishak, R. (2015). Impact of Working Capital Management, Ownership Structure and Board Size on the Profitability of Small and Medium-sized Entities in Nigeria. International Journal of Economics and Financial Issues, 5(special issue), 77-83.

73.Turley, S., \& Zaman, M. (2004). The corporate governance effects of audit committees. Journal of management and governance, 8(3), 305-332.

74.Turner, L. E., Williams, J. P., \& Weirich, T. R. (2005). An inside look at auditor changes. The CPA Journal, 75(11), 12-21.

75.Vafeas, N. (2005). Audit committees, boards, and the quality of reported earnings. Contemporary accounting research, 22(4), 1093-1122.

76.Visvanathan, G. (2008). Corporate governance and real earnings management. Academy of Accounting and Financial Studies Journal, 12(1), 9-136.

77.Xie, B., Davidson, W. N., \& DaDalt, P. J. (2003). Earnings management and corporate governance: the role of the board and the audit committee. Journal of corporate finance, 9(3), 295-316.

78.Yermack, D. (1996). Higher market valuation of companies with a small board of directors. Journal of financial economics, 40(2), 185-211. 